\title{
Institutional Dimension of Investment Profile, Natural Resources \& Foreign Direct Investments: A Case of MENA Oil Producing Countries
}

\author{
Sahar Hassan Khayat ${ }^{1}$ \\ ${ }^{1}$ Department of Economics, Faculty of Economics and Administration, King Abdul-Aziz University, Jeddah, \\ Saudi Arabia \\ Correspondence: Sahar Hassan Khayat, Assistant Professor, Department of Economics, Faculty of Economics \\ and Administration, King Abdul-Aziz University, P. O. Box 3024, Jeddah 21471, K.S.A, Saudi Arabia. Tel: \\ 966-505-646-027. E-mail: skhayat@kau.edu.sa; saharkayat@hotmail.com
}

Received: May 18, 2017

doi:10.5539/ijef.v9n8p33
Accepted: June 5, 2017

Online Published: July 5, 2017

URL: https://doi.org/10.5539/ijef.v9n8p33

\begin{abstract}
The economic development of countries depends on the flow of foreign direct investment. The natural resources are responsible for maximum attraction of FDI in MENA countries. The study has aimed to examine the impact of institutional dimension of investment profile and natural resources on the flow of foreign direct investment in MENA countries. The study has included 17 MENA countries for the generation of incomplete and unbalanced panel data for the years 1960-2012. The study has considered FDI as dependent variable; while, the independent variables include location dimension, institutional dimension, new theory trade, and other economic determinants. The basic dunning OLI paradigm is combined with different variables; and the results were compared with previous studies. The flow of FDI in MENA countries is affected by different natural resources. The application of resource curse to FDI flow in MENA countries represents the negative correlation between energy endowment and FDI flow. The results showed that oils rents are not statistically significant. Moreover, investment profile and oil relative production were negatively correlated. The importance of natural resources and FDI determinants in MENA countries has been determined in the present study.
\end{abstract}

Keywords: economic development, foreign direct investment, institutional quality, investment profile, MENA countries, natural resources

\section{Introduction}

In developing countries, the economic development and growth significantly depend on the flow of foreign direct investment (FDI). As compared to the year 2010, 16\% increase has been observed in foreign direct investment in the year 2011 (Ezeoha \& Cattaneo, 2012). The production of petroleum has been fully owned by the private sectors after the industrial revolution. However, natural resources are considered as major factors in developing countries such as Middle East and North Africa (MENA) region for maximum attraction of FDI. The countries of MENA region attract profound flow of FDI, despite of being the richest oil-producing countries in the world (Onyeiwu, 2003).

The maximum attraction of FDI into MENA region is necessary because capital inflow is considered as an important source of revenue. It also help in building strong association between international corporations, different countries, and international monetary agencies (Asiedu \& Lien, 2011). Past literature has indicated the impact of investment profile of FDI among the non-resource exporting and source exporting countries. However, this study has analyzed the natural resources, which alter the association between investment profile and FDI.

Global Foreign Direct Investment flows have been raised by $29 \%$ to $\$ 916$ billion in 2005, compared to $27 \%$ in 2004 (UNCTAD, 2006). Figure 1 has shown that FDI and direct investment stock have been increased by $3 \%$ across the globe. 


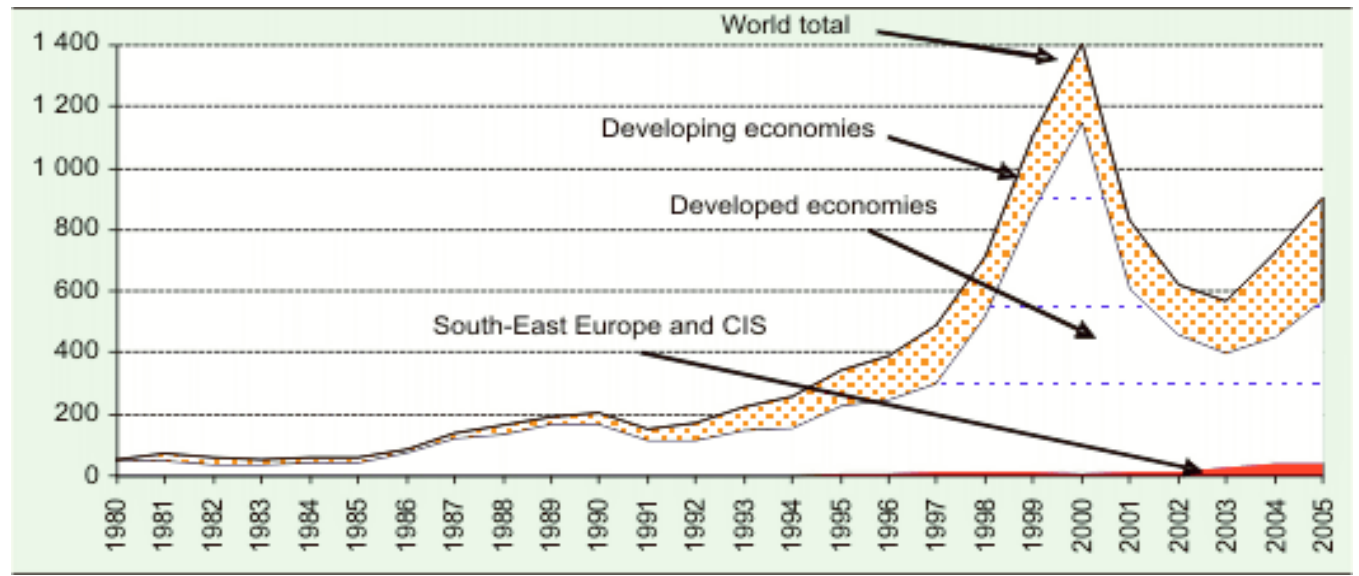

Figure 1. FDI Inflows, global and by group of economies, 1980-2005

Source: UNCTAD, based on its FDI/TNC database; www.unctad.org/fdi statistics.

UNCTAD World Investment Report has indicated that Foreign Direct Investment inflows were increased by 22\% among developing countries (recorded at $\$ 334$ billion). At the same time total inflows were increased from $20 \%$ to $35 \%$ from 1978 to 2005 . On the contrary, MENA countries have received the FDI inflows of $127 \%$ in 2005. Similarly, the report has also indicated that FDI was progressed from $\$ 17$ billion in 2004 to $\$ 31$ billion in 2005 in Africa. Therefore, such investment was concentrated in mining, oil, and gas from South Africa, UK, USA, India, China, and Brazil. Moreover, the global FDI share was decreased from 10\% in 1978-1980 to 5 percent in 1998-2000. In accordance with the report, following are the top FDI flows in oil-producing countries:

- $\quad$ Algeria $=55 \%$

- $\quad$ Egypt $=37 \%$

- $\quad$ Nigeria $=80 \%$

- $\quad$ Sudan $=90 \%$

Getting specified to North Africa, it has been identified that FDI level was increased by $42 \%$ to $\$ 13$ billion of total FDI inflows in Africa (UNCTAD, 2006). During the same period, Egypt, Morocco, Sudan, Algeria and Tunisia have also attracted similar FDI inflows in North Africa during 2005. Increased FDI inflows within Egyptian market was $\$ 5.4$ billion, resulted from a strong increase in investment in the petroleum industry with privatization programs (UNCTAD, 2006). The major FDI inflow in Morocco and Tunisia was privatization programs. Furthermore, Egypt has reformed the tax system to reduce corporate income tax.

The flow of FDI in European countries depends upon the method of privatization and risk prevailing in the country. The share of private market is as high as $80 \%$ in the Republic of Hungary and Czech. A good amount of FDI is attracted by Slovenia and Slovak Republic due to the stability within the country and high share of private business (Carstensen \& Toubal, 2004). The position of US, specifically in Visegrad countries, is non-negligible as countries like Poland and Hungary absorb approximately $90 \%$ of the total investments from US. The growth of FDI in the economies of UK and Germany is dependent on the specific knowledge-based assets. It shows that the investments within a country are significant channels for the diffusion of technologies and ideas (Barrell \& Pain, 1997).

The paper has further discussed the literature based on investment profile, natural resources, and FDI. It has also discussed the methodology that has been implemented in the study. Moreover, the results and discussion have been presented on the basis of investigation, done on the empirical determinants of FDI.

\subsection{Contribution of the Study}

The study has investigated the association between FDI, natural resources, and investment profile. The study has revealed that the effects of investment profile on FDI are dependent on the significance of natural resources in the exports of host country. FDI is supported in the countries by the investment profile, when there is a decrease in the share of natural resources within the total exports. The results have significant implications for the MENA countries. Moreover, this study has selected MENA countries, different from the developing countries, in regards of FDI flow. 


\section{Literature Review}

There are limited studies, conducted to investigate the determinants of FDI inflow in the MENA countries (Moosa, 2009; Mohamed \& Sidiropoulos, 2010). Although, there is vast literature on FDI determinants, but limited studies have addressed investment profile as an explanatory variable. Therefore, this study aims to examine the impact of openness to trade, oil, inflation rate, infrastructure development, market size, institutional quality in host countries, and capital. The flow of FDI is extensively driven by access to natural resources in host countries. However, FDI is accordingly controlled by the government sector; and the presence of natural resources within a country is considered to be of financial, political, and strategic importance (Asiedu \& Lien, 2011).

\subsection{Investment Profile}

There are different sources that are responsible for providing ratings at the level of investment profile in countries across the globe. A study conducted by Casper and Tufis (2003) revealed that three different measures of investment profile are needed to be implemented for increasing the credibility of the results from various sources. It has been further argued that investment profile entails a proper competition among the candidates for different public offices and citizens participation after the end of election.

Different scholars have identified that this definition has included various dimensions, including political rights; civil liberties; socioeconomic equality; uncertainty; and the absence of military influence. Moreover, significant number of investment profile have the ability to diversify such definitions. Some of the common measures include polity, polyarchy, freedom house, political regime change, and development. It is common that their measures are correlated with the reliability of different measures. However, these measures have a direct correlation for measuring time period covered, and number of countries.

\subsection{Natural Resources}

The natural resource export intensity of a country is captured through different measures of natural resources including:

- Share of minerals in total merchandise exports

- Share of fuel in total merchandise exports

- Share of fuel and minerals in total merchandise exports

In accordance with market-seeking effects, the goods produced and sold in domestic markets have a closer relationship with the market size, access to regional and global markets, market growth, structure of markets, and country-specific consumer preferences. The analysis has shown that FDIs are significant aspects for transnational corporations (TNCs) in developing country markets. The real GDP for market size determinants has a positive impact on FDI. Therefore, a large market can receive enhanced foreign direct investment inflows. In accordance with analytical framework, it has been estimated that panel data technique has a direct relevance with 153 countries over the period 1980-2004. The findings have shown that GDP has a positive and significant impact on FDIs. Moreover, the determinants of FDI in BRICS economies have concluded that GDP is positive and significant impact on FDI. Following are the research questions that have been considered for analysis:

1) What is the significance of natural resources to attract maximum FDI inflow in the MENA region?

2) Are the natural resources capable of altering the association between institutional quality and FDI?

3) Do the natural resources mitigate positive influence of institutional quality and FDI?

\section{Methodology}

The study has combined the basic dunning OLI paradigm with different variable and relate it with previous literatures. 17 MENA countries were included in the study to generate an unbalanced and incomplete panel data between the years 1960 and 2012. FDI was considered as a dependent variable; whereas, location dimension, institutional dimension, new theory trade, and other economic determinants were considered as independent variable. The study has investigated the empirical determinants of FDI, using panel data of 17 MENA countries. Previous results have indicated that different natural resources have different impact of FDI in MENA countries.

The natural resources are not always resource seeking. However, the application of resource curse to FDI in the MENA region depicts that the energy endowment of a country negatively correlates with FDI. The location dimension was comprised of inflation, infrastructure, and human capital. The inflation variable is one of the most common control variables in empirical FDI inflows. Therefore, the study has used the inflation of consumer prices annually as a percentage. Additionally, inflation rate was included for recording the general price levels in 
each country. Inflation is expected to have both a negative and positive sign. Infrastructure is considered as one of the most fundamental determinants in regards to FDI; therefore, a positive relationship is expected.

The study has selected school enrollment, [secondary (\% gross)] as a proxy for human capital; therefore, a positive relationship is expected between human capital and FDI. The proxies, which have been utilized to represent natural resource endowment for assessing inflows mainly include fuel exports, oil rents, and oil resources. The first approach is related with oil extraction that can be measured by oil production. The second approach is oil exploration (oil potential) that can be measured by oil reserves. The third approach is the association between oil explorations and oil extraction, which is related to production relative to oil reserves. Natural resources endowment is expected to have both a negative and positive sign.

\section{Results and Discussion}

The study has investigated the empirical determinants of FDI, using panel data of 17 MENA countries. The results indicated that different natural resources have different impact of FDI in MENA countries. The natural resources are not always resource seeking. Moreover, the application of resource curse to FDI in the MENA region depicts that the energy endowment of a country negatively correlate with FDI. The present study has estimated the models of foreign direct investment inflow by Fixed Effects (FE) method. The fixed effect method was significantly helpful to evaluate robustness of acquired result. The study has also compared the result with previous literature. The study depicted that there was no statistical significance of exchange and interest rates. The 5 alternative measures of natural resource endowment including; oil rents, oil reserves, fuel exports, oil production, and oil productive related to oil reserves have been used in the baseline models. Along with alternative measures of natural resource endowment, other dependent variables were also used to define the baseline models. The dependent variable interact with different types of investment profile and natural resource for institutional quality.

The study has further examined the fixed effects of all the models without considering any interactions; however, Hausman test recommend to use the fixed effects in all the models. The production of natural gas plant liquids, crude oil, refined goods, and other liquids are included in the International Energy Statistical Strategies. A net refinery processing loss is indicated through the values of negative refinery processed data.

The results revealed an average of 1.6\% FDI with standard deviation of 3.19\% and average inflation of $9.69 \%$ with standard deviation $28.16 \%$. Moreover, the average natural logarithm of GDP constant is calculated to be $23.83 \%$; whereas, the average of fuel in natural logarithm is estimated to be $2.69 \%$ (Table 1).

Table 1. Correlation coefficient matrix

\begin{tabular}{|c|c|c|c|c|c|c|c|c|c|c|c|c|}
\hline & FDIIN & Trade & GDP & Inflation & Infrastructure & $\begin{array}{r}\text { Human } \\
\text { capital }\end{array}$ & Investment & Fuel & $\begin{array}{c}\text { Oil } \\
\text { rents }\end{array}$ & $\begin{array}{c}\text { Oil } \\
\text { production }\end{array}$ & $\begin{array}{c}\text { Oil } \\
\text { reserves }\end{array}$ & $\begin{array}{c}\text { Oil (relative } \\
\text { production) }\end{array}$ \\
\hline FDIIN & 1 & & & & & & & & & & & \\
\hline Trade & 0.48 & 1 & & & & & & & & & & \\
\hline GDP & 0.08 & -0.26 & 1 & & & & & & & & & \\
\hline Inflation & -0.09 & -0.31 & 0.08 & 1 & & & & & & & & \\
\hline Infrastructure & 0.11 & 0.32 & 0.23 & -0.26 & 1 & & & & & & & \\
\hline Human capital & 0.30 & 0.45 & 0.27 & -0.15 & 0.70 & 1 & & & & & & \\
\hline Investment & 0.36 & 0.30 & 0.16 & -0.45 & 0.31 & 0.42 & 1 & & & & & \\
\hline Fuel & -0.23 & -0.21 & 0.31 & 0.11 & 0.40 & 0.31 & 0.16 & 1 & & & & \\
\hline Oil rents & -0.08 & 0.10 & 0.37 & -0.02 & 0.62 & 0.46 & 0.29 & 0.78 & 1 & & & \\
\hline Oil production & 0.08 & -0.01 & 0.85 & 0.03 & 0.42 & 0.39 & 0.21 & 0.52 & 0.64 & 1 & & \\
\hline Oil reserves & 0.05 & 0.10 & 0.73 & -0.04 & 0.56 & 0.44 & 0.21 & 0.46 & 0.70 & 0.94 & 1 & \\
\hline $\begin{array}{l}\text { Oil (relative } \\
\text { production) }\end{array}$ & -0.05 & -0.07 & 0.01 & -0.08 & -0.15 & -0.25 & 0.08 & -0.26 & -0.22 & -0.14 & -0.12 & 1 \\
\hline
\end{tabular}

The table shows that there is a good variation within a country and between different countries, which facilitated the use of dynamic panel estimation. There is a strong correlation between human capital and infrastructure; however, the correlation has no concerns because it does not involve the regression analysis at the same time. Moreover, strong correlation is also depicted between oil rents and oil reserves; and, oil rents and oil production (Table 1).

Table 2 has presented 4 different models among which the first and second model are termed as alternative 
models because they used fuel to measure natural resources. Whereas, the third and fourth model utilized the oil rents for alternative measurement of natural resources (Table 2). $1 \%$ significance was observed for the fixed effects that estimated the positive impact of fuel exports on the flow of FDI. These results are consistent with previous studies (Asiedu, 2006; Mohamed \& Sidiropoulos, 2010).

Table 2. Dependent variable: Inward FDI percentage of GDP, panel analysis, country fixed-effects (model based on correlation matrix). Impact of Fuel and Oil Rents

\begin{tabular}{|c|c|c|c|c|}
\hline Regressor & $(1)$ & (2) & (3) & (4) \\
\hline \multirow[t]{2}{*}{ Ln TRADE } & 1.782 & 2.032 & 2.067 & 1.534 \\
\hline & $(0.166)$ & $(0.292)$ & $(0.182)$ & $(0.408)$ \\
\hline \multirow[t]{2}{*}{ Ln FUEL } & $1.610 * * *$ & $1.324 * * *$ & & \\
\hline & $(0.000)$ & $(0.000)$ & & \\
\hline \multirow[t]{2}{*}{ OIL RENTS } & & & -0.067 & -0.048 \\
\hline & & & $(0.369)$ & $(0.434)$ \\
\hline \multirow[t]{2}{*}{ Ln GDP } & $4.030 * * *$ & $4.406 * * *$ & $5.687 * *$ & $5.081 * *$ \\
\hline & $(0.001)$ & $(0.001)$ & $(0.033)$ & $(0.010)$ \\
\hline \multirow[t]{2}{*}{ INFLATION } & $0.076^{*}$ & $0.069^{* *}$ & 0.078 & $0.0898 * *$ \\
\hline & $(0.097)$ & $(0.035)$ & $(0.103)$ & $(0.036)$ \\
\hline \multirow[t]{2}{*}{ INFRASTRUCTURE } & & -0.001 & & -0.0434 \\
\hline & & $(0.981)$ & & $(0.644)$ \\
\hline HUMAN CAPITAL & -0.011 & & -0.052 & \\
\hline (Education) & $(0.534)$ & & $(0.229)$ & \\
\hline INSTITUTION & 0.020 & -0.023 & 0.234 & 0.144 \\
\hline (Investment profile) & $(0.902)$ & $(0.872)$ & $(0.383)$ & $(0.535)$ \\
\hline \multirow[t]{2}{*}{ CONSTANT } & $-106.2 * * *$ & $-117.35^{* * *}$ & $-141.36^{* *}$ & $-128.05^{* *}$ \\
\hline & $(0.001)$ & $(0.000)$ & $(0.031)$ & $(0.010)$ \\
\hline \multicolumn{5}{|l|}{$\begin{array}{c}\text { Collinearity diagnostics } \\
\text { (VIF) }\end{array}$} \\
\hline TRADE & 2.91 & 2.56 & 2.95 & 2.25 \\
\hline FUEL & 1.60 & 1.78 & & \\
\hline OIL RENTS & & & 1.53 & 1.53 \\
\hline GDP constant & 2.13 & 1.88 & 2.30 & 1.84 \\
\hline INFLATION & 1.42 & 1.35 & 1.49 & 1.50 \\
\hline INFRASTRUCTURE & & 1.62 & & 1.72 \\
\hline $\begin{array}{l}\text { HUMAN CAPITAL } \\
\text { (Education) }\end{array}$ & 1.76 & & 1.94 & \\
\hline INSTITUTION & 1.68 & 1.61 & 1.68 & 1.65 \\
\hline \multicolumn{5}{|l|}{ (Investment profile) } \\
\hline Mean VIF & 1.92 & 1.80 & 1.98 & 1.75 \\
\hline N. Observations & 176 & 229 & 194 & 266 \\
\hline N. Countries & 13 & 14 & 14 & 15 \\
\hline \multirow[t]{2}{*}{ F test } & $98.03 * * *$ & $29.61 * * *$ & $5.97 * * *$ & $22.59 * * *$ \\
\hline & $(0.0000)$ & $(0.0000)$ & $(0.0035)$ & $(0.0000)$ \\
\hline \multirow[t]{2}{*}{ Hausman test } & $42.19 * * *$ & $74.38^{* * * *}$ & $11.96^{*}$ & $20.15^{* * *}$ \\
\hline & $(0.0000)$ & $(0.0000)$ & $(0.0628)$ & $(0.0026)$ \\
\hline
\end{tabular}

P-value in parentheses, *significant at $10 \%, * *$ significant at $5 \%, * * *$ significant at $1 \%$.

The results further suggested that FDI is highly encouraged in MENA countries. The oil rents are included in the exports of alternative fuels as they are a type of proxy for the natural resources. The factors, related to natural resources, were not statistically significant in the regression. A positive significance of $1 \%$ was depicted in model 1 and 2; whereas, model 3 and 4 represented 5\% of significance for measuring the market size GDP constant (Hisarciklilar et al., 2006; Mohamed \& Sidiropoulos, 2010). 10\% significance and positive inflation have been observed in the first model; while, the second and fourth models depicted significance of 5\%. These results are consistent with the previous studies (Dhakal et al., 2007; Botric \& Skuflic, 2006). 
Table 3 has shown the results, derived from the GMM estimators. The results depicted that FDI does not influence the economic growth; therefore, it stated that there is no significant association between FDI and economic growth of the country. At $10 \%$ level, the co-efficient of FDI and FDI-openness to trade are insignificant. Depending upon income per capita, there is no growth effect of FDI; however, the coefficients of FDI and FDI income per capita are not significant at $10 \%$ level. When inflation exceeds 15.49 , there is a negative influence of FDI on economic growth of the country (Table 3). Therefore, it has been revealed that the association between FDI and economic growth depends upon the macroeconomic stability of country (Sadni-Jallab et al., 2009).

Table 3. Two-step dynamic panel data estimation GMM model (5 year observation)

\begin{tabular}{|c|c|c|c|c|c|}
\hline Independent Variables & Difference GMM (1) & System GMM (2) & Difference GMM (3) & Difference GMM (4) & Difference GMM (5) \\
\hline $\begin{array}{c}\log \text { Real per capita } \\
\text { GDP(t-1) }\end{array}$ & $0.7235 * * *(0.1281)$ & $0.8162 * * *(0.0210)$ & $1.0347 * * *(0.1387)$ & $0.8107 * * *(0.0858)$ & $0.8652 * * *(0.1257)$ \\
\hline $\begin{array}{l}\text { Foreign Direct } \\
\text { Investment }\end{array}$ & $-0.3992(0.7642)$ & $0.0301(0.0307)$ & $0.8316 * * *(0.3192)$ & $-0.2249(0.3429)$ & $-0.8349(0.9903)$ \\
\hline $\begin{array}{c}\text { FDI } \times \log \text { Real per } \\
\text { capita GDP }\end{array}$ & & & & & $0.2267(0.2482)$ \\
\hline FDI $\times$ Inflation & & & $-0.0537 * * *(0.0066)$ & & \\
\hline FDI $\times$ Openness & & & & $0.0036(0.0036)$ & \\
\hline Period 1990-1994 & $-0.2181(0.2215)$ & $0.1333(0.0962)$ & $-0.0081(0.2185)$ & $-0.1786(0.1292)$ & $0.0009(0.1415)$ \\
\hline Period 1995-1999 & $-0.2092(0.5662)$ & $0.4384 *(0.2646)$ & $0.3887(0.4557)$ & $0.0369(0.2352)$ & $0.1932(0.2078)$ \\
\hline Period 2000-2004 & $-0.4956(0.4374)$ & $0.0639(0.1166)$ & $-0.2139(0.2227)$ & $-0.2901(0.2399)$ & $0.0772(0.3221)$ \\
\hline Period 2005-2009 & $-0.4100(0.3238)$ & $0.1538(0.0961)$ & $-0.1850(0.2788)$ & $-0.2375(0.2637)$ & $0.1561(0.3501)$ \\
\hline Period 2010-2015 & $0.1918(0.7586)$ & $0.2999 * * *(0.1100)$ & $-0.8025(0.3959)$ & $-0.1476(0.1949)$ & $0.5862(0.8369)$ \\
\hline $\begin{array}{l}\text { Arellano-Bond test for } \\
\qquad \operatorname{AR}(2) \text { in first } \\
\text { differences: p-value }\end{array}$ & 0.353 & 0.274 & 0.201 & 0.321 & 0.293 \\
\hline $\begin{array}{c}\text { Hansen test of } \\
\text { over-identification } \\
\text { Restrictions: p-value }\end{array}$ & 0.426 & 0.616 & 0.3080 & 0.411 & 0.417 \\
\hline
\end{tabular}

A study conducted by Asiedu and Lien (2011) revealed that the energy reserves in MENA countries are under control of state-owned entities. The oil production of $1 \%$ as a proxy for natural resources is responsible for decreasing the inflow of FDI by 0.1\% (Mina, 2007; Mina, 2012). Moreover, a study conducted by Mina (2009) indicated the negative coefficient of oil production at significance level of 5\% in the second model. However, human capital, trade, investment profile, and infrastructure have not provided significant results. There is a negative correlation between oil relative production and investment profile. However, Asiedu and Lien (2011) indicated that the negative correlation determined the positive impact of investment profile on the FDI in MENA countries.

\section{Conclusion}

The impact of natural resources varies on the inflow of FDI in MENA countries. The natural resources; like oil production, oil reserves, oil rents and oil production related to oil reserves, negatively affected the inflow of FDI; whereas, the export of fuel is likely to attract maximum FDI in MENA countries. The main determinants of FDI inflow in MENA countries are GDP, trade openness, inflation rate, market size, and investment profile, which measured the institutional quality. The type of natural resource defined the impact of investment profile on FDI. There is a negative correlation between fuel exports and inward flow of FDI in MENA countries. It shows that the production of oil in MENA countries is dependent on the institutional quality. The study has also highlighted the significance of natural resources and determinants of FDI in MENA countries. In order to attract maximum FDI, the MENA countries need to implement two policy measures:

- Liberalization of trade within MENA countries

- Implement far-reaching privatization programs to reduce size of the government.

The privatization reduces bureaucracy and corruption by decreasing government's scope. The MENA countries need to accept that maximum FDI can be attracted by improving country's macroeconomic performance. The 
MENA countries need to sequence their major policy measures, try to improve their economic fundamentals, and focus on trade liberalization and privatization. The future research needs to investigate all the determinants of FDI that affect the flow of FDI in MENA as well as non-MENA countries.

\section{Acknowledgement}

The author is very thankful to all the associated personnel in any reference that contributed in/for the purpose of this research.

\section{References}

Asiedu, E. (2006). Foreign direct investment in Africa: The role of natural resources, market size, government policy, institutions and political instability. The World Economy, 29(1), 63-77. Doi: https://doi.org/10.1111/j.1467-9701.2006.00758.x

Asiedu, E., \& Lien, D. (2011). Democracy, foreign direct investment and natural resources. Journal of International Economics, 84(1), 99-111. https://doi.org/10.1016/j.jinteco.2010.12.001

Barrell, R., \& Pain, N. (1997). Foreign direct investment, technological change, and economic growth within Europe. The Economic Journal, 107(445), 1770-1786. https://doi.org/10.1111/j.1468-0297.1997.tb00081.x

Botric, V., \& Skuflic, L. (2006). Main determinants of foreign direct investment in the southeast European countries. Transition Studies Review, 13(2), 359-377. https://doi.org/10.1007/s11300-006-0110-3

Carstensen, K., \& Toubal, F. (2004). Foreign direct investment in Central and Eastern European countries: A dynamic panel analysis. Journal of Comparative Economics, 32(1), 3-22. https://doi.org/10.1016/j.jce.2003.11.001

Casper, G., \& Tufis, C. (2003). Correlation versus interchangeability: The limited robustness of empirical findings on democracy using highly correlated data sets. Political Analysis, 196-203. https://doi.org/10.1093/pan/mpg009

Dhakal, D., Mixon Jr, F., \& Upadhyaya, K. (2007). Foreign direct investment and transition economies: Empirical evidence from a panel data estimator. Economics Bulletin, 6(33), 1-9.

Ezeoha, A. E., \& Cattaneo, N. (2012). FDI flows to sub-Saharan Africa: The impact of finance, institutions, and natural resource endowment. Comparative Economic Studies, 54(3), 597-632. https://doi.org/10.1057/ces.2012.18

Hisarciklilar, M., Kayam, S. S., \& Kayalica, O. (2006). Locational Drivers of FDI in MENA Countries: A spatial Attempt.

Mina, W. (2007). The location determinants of FDI in the GCC countries. Journal of Multinational Financial Management, 17(4), 336-348. https://doi.org/10.1016/j.mulfin.2007.02.002

Mina, W. M. (2012). The institutional reforms debate and FDI flows to the MENA region: the "best" ensemble. World Development, 40(9), 1798-1809. https://doi.org/10.1016/j.worlddev.2012.04.026

Mohamed, S. E., \& Sidiropoulos, M. G. (2010). Another look at the determinants of foreign direct investment in MENA countries: An empirical investigation. Journal of Economic Development, 35(2), 75.

Moosa, I. A. (2009). The determinants of foreign direct investment in MENA countries: An extreme bounds analysis. Applied Economics Letters, 16(15), 1559-1563. https://doi.org/10.1080/13504850701578819

Onyeiwu, S. (2003, December). Analysis of FDI flows to developing countries: Is the MENA region different. In ERF 10th Annual Conference, December, Marrakech, Morocco.

Sadni-Jallab, M., Gbakou, M., \& Sandretto, R. P. (2009). Foreign direct investment, macroeconomic instability and economic growth in MENA countries.

UNCTAD. (2006). World Investment Report: FDI from Developing and Transition Economies: Implications for Development. United Nations Conference on Trade and Development, United Nations, New York and Geneva.

\section{Copyrights}

Copyright for this article is retained by the author(s), with first publication rights granted to the journal.

This is an open-access article distributed under the terms and conditions of the Creative Commons Attribution license (http://creativecommons.org/licenses/by/4.0/). 